\title{
IMPACT OF FIXED ASSETS SHARE AND PROFITABILITY ON USE OF DEBT SOURCES OF COMPANIES IN THE BUILDING INDUSTRY IN V4 COUNTRIES
}

\author{
[Vliv podílu dlouhodobého majetku a rentability na využití cizích zdrojů \\ financování firem v odvětví stavebnictví v zemích V4]
}

\author{
Petra Růčková ${ }^{1}$ \\ ${ }^{1}$ Slezská univerzita, Obchodně podnikatelská fakulta, Univerzitni nám. 1934/3,733 40 Karviná \\ Email:ruckova@opf.slu.cz
}

\begin{abstract}
Abstrakt: The paper deals with an analysis of impact of selected factors onto the level of use of debt sources in companies in the building industry in V4 countries from 2006 to 2013. The building branch is considered an indicator of development of an economic cycle, so in the context of the current economic cycle the choice of just this industry was adequate. The aim of the paper is to perform an analysis by means of panel regression and correlation and, based on this, to find the impact of fixed assets on assets and the impact of return on equity on the use of debt sources in companies in the building industry in conditions of the V4. The choice of factors is conditioned by prior studies as well as by financial environment where these companies operate. The analysis is done at two levels. The first level monitors the relations on average values in building in individual countries. The latter value processes data by means of panel regression on a sample of building companies in the category of large to medium companies in individual countries. The results indicate whether the generally valid theories are met in the real environment of economies in Central Europe.
\end{abstract}

Klíčová slova: building, debt capital, debt/equity ratio, equity capital, financial resources, return on equity, tangible assets, Visegrad Group (V4).

JEL kódy: G32

Doručeno redakci: 9.2.2015; Recenzováno: 4.3.2015; 1.4.2015; Schváleno k publikování: 23.9.2015

\section{Úvod}

Podniky v různých odvětvích a v různých fázích životního cyklu podniku využívají odlišným způsobem zdroje financování. Rozhodování může být ovlivněno mnoha faktory, nicméně firma má možnost disponovat pouze vlastními nebo cizími zdroji financování, zdroji interními a externími. Rozhodování o tom, který ze zdrojů financování bude použit, vyplývá z nastavení vnitřní finanční politiky podniku a z vnějších aspektů, které mohou dostupnost př́slušných zdrojů ovlivnit. Cílem článku je na základě analýzy pomocí panelové regrese a korelace zjistit vliv podílu dlouhodobého majetku a rentability vlastního kapitálu na využití cizích zdrojů financování ve firmách v odvětví stavebnictví v podmínkách Visegradské čtyřky. Výběr faktorů je postaven na níže uvedených studiích.

\section{Metodologie a data}

Většina studií zabývajících se finančním řízením společností předpokládá, že v rámci zdrojů financování bude využíváno co nejširšího spektra zdrojů financování a že v nějaké podobě bude používáno dluhové financování. Jednotlivé studie se liší podle toho, zda se prioritně snaží o maximalizaci účetní hodnoty nebo je primárním zájmem hodnota tržní. Liší se také v tom, zda využívají veškeré dluhové formy financování nebo zda využívají pouze dlouhodobé dluhové formy financování. Někteří autoři studií o kapitálové struktuře proto mají tendenci nahrazovat ukazatel debt ratio nebo debt/equity ratio (dále již jen $\mathrm{D} / \mathrm{E}$ ) podílem finančních nákladů a objemu dluhu, tedy úrokovou mírou. Evropa není primárně postavena na veřejně obchodovatelných společnostech a využívá i ve velmi významné míře právní 
uspořádání, které neumožňuje kontinuálně pracovat s tržní hodnotou. Tržní ocenění se stává velmi nákladnou záležitostí. Angloamerický model je charakteristický tím, že je většina společností obchodována na veřejných kapitálových trzích, což znamená, že odvozování tržní hodnoty se děje na základě součinu tržní hodnoty akcie a počtu emitovaných akcií. Také proto Barclay, Morellec a Smith (2001) ve své studii postavené na zkoumání společností na americkém kapitálovém trhu argumentují, že není důvod stavět na retrospektivních informacích, když existují informace perspektivní. Vzhledem k tomu, že je pozornost zaměřena na společnosti v rámci Evropy a že se zde vyskytují i společnosti jiného typu než akciové společnosti, budou jako vstupní údaje pro analýzu využívána účetní data společností. Pozornost byla zaměřena na oblast stavebnictví, nebot' toto odvětví bývá označováno jako indikátor vývoje ekonomického cyklu. Zatímco do roku 2007 lze v tomto odvětví sledovat růst, od roku 2008 je zřetelný trend propadu pozemního stavitelství, ke kterému se přidal i pokles inženýrského stavitelství (v letech 2008 - 2009 ještě inženýrské stavitelství dokázalo propad pozemního stavitelství vyrovnat). Za špatnou kondicí odvětví stály zpožděné dopady globální hospodářské krize, především pokračující slabá poptávka domácností i firem.

Z odvětví stavebnictví byly získány údaje za jednotlivé podniky v kategorii velmi velké, velké a střední firmy z databáze Amadeus. Malé podniky byly z analýzy vyřazeny ze dvou důvodů. Prvním důvodem byla slabá dostupnost dat, druhým důvodem byla skutečnost, že primárním zájmem z hlediska řízení malých společností není korekce způsobů financování. Obecně lze říci, že malé podniky mají menší možnosti z hlediska volby zdroje financování než podniky střední a velké velikosti. Z vygenerovaného souboru byly odstraněny podniky, které nesplnily podmínku ucelené časové řady za léta 2006 až 2013, tzn. že nesměla v časové řadě chybět hodnota sledovaných položek za více než tři roky. Nastavení časové řady vycházelo $\mathrm{z}$ dostupnosti údajů $\mathrm{v}$ databázi. Zkoumaný vzorek na základě splnění těchto podmínek obsahuje v České republice 506 podniků, v Mad'arsku 14, v Polsku 354 a na Slovensku 83. Na první pohled je zřejmě zarážející počet společností v Mad'arsku, nicméně je to celkový počet firem bez jakýchkoliv úprav, který byl generován z databáze Amadeus na základě stejných výběrových parametrů jako u ostatních zemí. Data jsou podkladem pro zpracování panelové regrese. Při konstrukci panelového regresního modelu budu vycházet ze studie Haas a Lelyveld (2010). Dostatečně široká datová základna v průřezu panely jednotlivých proměnných umožňuje užitím regresní metody náhodných momentů (GMM) dosáhnout robustních výsledků, a to i přes krátký sledovaný úsek. Prucha (2014) uvádí, že mnohá panelová data trpí problémem kratší časové řady a $\mathrm{z}$ hlediska panelové regrese užitím metody nejmenších čtverců na tempech růstu jsou tak zcela nevhodná k jejímu použití. Metoda náhodných momentů (Generalized Method of Moments, GMM) dle něj představuje způsob, jak zkoumat funkční vztahy právě mezi takovými panelovými daty. Finanční data na roční frekvenci, získána ze základních účetních výkazů, uspořádána $\mathrm{v}$ panelech, jsou $\mathrm{z}$ tohoto důvodu vhodným kandidátem pro výzkum užitím této regresní metody. Velkou výhodou užití GMM oproti metodě nejmenších čtverců je rovněž fakt, že mezi regresory také figuruje zpožděná endogenní, vysvětlovaná, závislá proměnná (Hall, 2005). Vztah bude obecně modelován rovnicí (1):

$$
D E R_{i t}=\alpha_{1}+\beta_{1} * \Delta D E R_{i t-1}+\beta_{2} * X_{1 i t}+\beta_{3} * X_{2 i t}+\cdots \ldots \ldots \ldots+\beta_{n} * X_{n i t}+\varepsilon_{i t}(1)
$$

kde endogenní závislou proměnnou $D E R_{i t}$ bude ukazatel debt/equity ratio i-té proměnné $\mathrm{v}$ čase $\mathrm{t}$ hodnotící využití financování cizími zdroji, exogenními nezávislými proměnnými jsou zpožděná hodnota debt/equity ratio z předchozího roku $\Delta D E R_{i t-1}, X_{\text {nit }}$ budou ostatní faktory, které mohou míru využití cizích zdrojů financování ovlivnit. K těmto faktorům bude patřit objem dlouhodobého majetku (TANG) a rentabilita vlastního kapitálu (ROE). Symboly 
$\alpha_{1}$ a $\varepsilon_{i t}$ jsou konstantou modelu a reziduální složkou v modelu GMM. V rámci regrese bude zkoumána statistická významnost na hladině $1 \%, 5 \%$ a $10 \%$ na vzorku společností.

$\mathrm{Z}$ metodologického hlediska jsou použity především tři běžně užívané poměrové ukazatele. $\mathrm{D} / \mathrm{E}$ ratio hodnotí finanční strukturu společnosti. Do poměru vstupují cizí a vlastní zdroje financování využívané ve finančním hospodaření. Hodnoty vyšší než 1 signalizují větší využití cizích zdrojů financování, hodnoty nižší než jedna pak větší využití vlastních zdrojů. Dalším použitým ukazatelem je ukazatel podílu dlouhodobého majetku na celkovém objemu aktiv (TANG). Využití tohoto ukazatele vychází z myšlenky, že dlouhodobý majetek bývá označován jako efektivnější forma uložení finančních prostředků v rámci firemního hospodaření. Navíc je možné dlouhodobý majetek využít jako zástavu při využití cizích zdrojů financování. Tvoří určitou záruku pro partnery, kteří vstupují s podnikem do finančních vztahů. Posledním ukazatelem, na který bude zaměřena analýza, je ROE. Rentabilita vlastního kapitálu (return on equity - ROE) se využívá pro hodnocení efektivního nakládání s prostředky vlastníků podniků. Ukazatel je konstruován jako podíl čistého zisku (EAT) podniku s hodnotou vlastního kapitálu. ROE obecně je považováno za jeden z nejdůležitějších ukazatelů hodnocení efektivnosti. Rentabilita vlastního kapitálu je zařazena jako nezávislá proměnná, nebot' při získávání zdrojů financování z bankovního sektoru hraje roli z hlediska stanovení ceny úvěru. Cena úvěru je pak i rozhodujícím faktorem o konečném rozhodnutí o využití nebo nevyužití úvěrového financování.

\section{Tvorba hypotéz na základě současného stavu poznání}

Zkoumání vlivu objemu dlouhodobého majetku ve vlastnictví podniků na míru využití cizích zdrojů financování vychází ze dvou základních aspektů. Prvním aspektem je stabilita a image společnosti, kde se předpokládá, že dostatečným objemem především hmotného dlouhodobého kapitálu disponuje zavedená společnost dbající o svůj rozvoj. Druhým aspektem je záruka. Dlouhodobý majetek je vnímán v rámci finančního systému orientovaného na bankovnictví jako záruka pro prrípad problémů, které mohou potenciálně nastat v době trvání vztahu banka věřitel. I přes tyto dva základní a poměrně jednoznačné aspekty vznikla celá řada studií, které se tímto vztahem zabývají a které je bud' potvrzují, nebo vyvracejí.

Velmi často je možné se setkat se závěrem, že mezi $\mathrm{D} / \mathrm{E}$ ratio a poměrem dlouhodobého majetku na celkových aktivech (TANG) existuje pozitivní korelace. I tento vztah řešily v minulosti mnohé studie různých autorů, např. Marsh (1982), Hart and Moore (1994). Již ze studie Scotta (1977) vyplývá, že emitování dlužnických cenných papírů dočasně zvyšuje hodnotu kapitálu poskytnutého akcionáři. Toto tvrzení podpořili Myers a Majluf (1984), nebot' jejich model ukazuje, že mohou existovat náklady spojené s emisí obligací, které znají pouze manažeři podniku, což způsobí informační asymetrii a potenciální investoři mohou tuto informaci nesprávně vyhodnotit a tím dočasně zvýšit hodnotu podniku. $Z$ hlediska existence stálých aktiv (zejména pak nemovitostí) se tato skutečnost bude nutně promítat do ceny dluhu, nebot' dluh bude za těchto okolností pořizován s nižšími náklady. Dalo by se očekávat, že firmy, které mohou využít tento kolaterál, budou také více inklinovat $\mathrm{k}$ dluhovému financování.

Stulz a Johnson (1985) argumentují, že existence stálých aktiv umožňuje jejich zapojení do řízení kapitálové struktury a snížit tak náklady dluhu, nebot' se pracuje s tzv. zajištěným dluhem. Ve firmách, které naopak disponují větším objemem nehmotných aktiv, jsou náklady na řízení kapitálové struktury vyšší, nebot' kontrola takovýchto aktiv je obtížnější. Stejně tak Johnson (1997) ve své studii tvrdí, že i pro firmy s větším objemem stálého majetku je obtížnější přejít na rizikovější projekty a tím i rizikovější formy financování. Stejně tak věřitelé budou mít větší ochotu poskytovat prostředky firmám s majetkem, který potenciálně 
může sloužit jako zástava. Z této diskuse pak vyplývá závěr, že existuje pozitivní vztah mezi využitím dluhu a objemem stálých aktiv.

Navíc je možno se domnívat, že tento vztah bude významnější v těch ekonomikách, u nichž jsou primárně získávány finanční prostředky z bankovního sektoru než v ekonomikách orientovaných na trhy. V rámci empirické studie došli např. Antoniou, Guney, Paudyal (2002) k závěru, že vztah využití dluhu a stálých aktiv je pozitivní v Německu, negativní ve Velké Británii a ve Francii je tato vazba nevýznamná. Význam zajištění úvěrů mohl být v době realizace studie způsoben zejména tím, že právní úprava fungování stavebních spořitelen, které patřily k největším poskytovatelům úvěrů, povolovala poskytování zajištěných úvěrů a nezajištěných směly poskytovat jen limitovaný objem. Opět je tedy možné argumentovat tím, že bankovně orientovaný systém primárně vede $\mathrm{k}$ využití cizích zdrojů financování z bankovního sektoru. Nevýznamnost vazby ve Francii zase mohl být způsoben tím, že v době studie byla prrijata novela zákona o konkurzu, což z hlediska financování způsobilo především to, že postupně podniky začaly přecházet na získávání zajištěných cizích zdrojů. Ve Velké Británii je podle této studie negativní vztah těchto veličin postaven na nevýznamné roli bankovních úvěrů ve firemních pasívech. Proto stálá aktiva nemají na získávání finančních prostředků př́liš velký vliv. Britské firmy vykazovaly významnější podíl využití vlastních zdrojů financování a krátkodobých cizích zdrojů.

Dalším argumentem pro hmotná aktiva je také skutečnost, že u hmotných aktiv se dá přirozeněji $\mathrm{v}$ době finanční tísně počítat $\mathrm{s}$ jejich odprodejem a nemusí být zvažováno převzetí řízení společnosti, což je přirozenější u nehmotného majetku. Jde tedy o nejlepší možné využití toho př́slušného aktiva. V této souvislosti je nutné zmínit, že v době finanční tísně preference hmotného aktiva vyplývá z potenciálu vyššího výnosu. Nehmotný majetek nemůže nikdy realizovat stejnou hodnotu pro všechny společnosti. Jde o náročnost technologickou, tedy fakt, že některé obory podnikání jsou náročnější na know how a patenty a obory, které je využívají v menším rozsahu. Opět je to zdůvodnění toho, že nehmotný majetek je problematicky uplatnitelný mimo svůj obor podnikání, což je znovu argumentem pro to, aby společnosti s vysokým podílem těžko uplatnitelného nehmotného majetku a jedinečností svého podnikání inklinovaly k nižší míře zadlužení. Tuto skutečnost řeší např́íklad studie Shleifera a Vishny (1992), která se zabývá problematikou toho, že firmy ve vysoce konkurenčním prostředí mají v př́padě finančních problémů pohotový finanční trh pro jejich řešení. Volba vyšší zadluženosti v těchto případech může vést $\mathrm{k}$ dočasné vyšší efektivnosti. $\mathrm{K}$ tomu je potřeba si ještě uvědomit, že velké společnosti budou obtížněji měnit podnikatelskou strategii, kterou by mohli poškodit své věřitele, např. energetické společnosti zabývající se výrobou energie. I tyto společnosti budou snáze získávat nové prostředky pro realizaci investičních rozhodnutí.

Rajan a Zingales (1995) konstatují, že s vyšším podílem dlouhodobého majetku roste i ochota věřitelů poskytovat úvěr a pákový efekt $\mathrm{z}$ využití cizích zdrojů by tak měl být vyšší. Titman a Wessel ve své studii (1998) tuto skutečnost potvrzují s odkazem na skutečnost, že firmy s vyšší úrovní dlouhodobých aktiv, které mají vysokou zástavní hodnotu, mají i větší ochotu využít cizí zdroje financování. To v následujících letech potvrdily i další studie, např. Michaelas et al. (1999), Frank a Goyal (2004), Bevan a Danbolt (2004) a Gaud a kol. (2005). Využití zajištěného zadlužení však nesouvisí pouze s tímto elementárním vztahem. Příčinnou souvislost lze nalézt ještě v kontextu zastupitelského konfliktu. Zde však tento vztah funguje opačně. Jak například Grossman a Hart (1982) tvrdí, zvýšenou míru zadlužení nepřipustí manažeři kvůli zvýšené hrozbě bankrotu, nebot' s růstem hrozby bankrotu klesá možnost konzumace požitků plynoucích z manažerské pozice. Především tato skutečnost vede k velmi důslednému využití dluhového financování a také jeho zajištění. To však zpětně směřuje $\mathrm{k}$ tomu, že společnosti s menším objemem aktiv, které mohou být použity k zajištění dluhu, 
budou z hlediska zastupitelského konfliktu zvažovat menší míru zadlužení, nebot' nedostatek vhodných aktiv zvyšuje náklady dluhu a tím také výrazněji snižuje míru požitků manažerů.

Se stálými aktivy v kontextu s řízením kapitálové struktury souvisí ještě existence nedluhového daňového štítu. Vyjadřuje úsporu, kterou podnik získá tím, že odpisy zahrnuje do nákladů a tím snižuje daňový základ. Je tedy zřejmé, že vliv nemovitostí má své dopady také na rentabilitu vlastního kapitálu. Dá se říci, že nedluhový daňový štít má substituční vliv vzhledem k úrokovému daňovému štítu na řízení kapitálové struktury. Tímto vztahem se zabývá ve své studii např́klad DeAngelo a Masulis (1980).

V kontextu $\mathrm{s}$ výše uvedenými studiemi budou v následujícím textu zkoumány následující hypotézy:

H1: S růstem objemu dlouhodobého majetku v majetkové struktuře podniku roste využití cizí zdroje financování.

H2: Větší využití cizích zdrojů financování je spojeno s rostoucím podílem dlouhodobého majetku a rostoucí efektivností podniku měřenou ROE.

\section{Vývoj průměrných hodnot jednotlivých ukazatelů a jejich vzájemný vztah ve stavebnictví v zemích Visegradské čtyřky v letech 2006 až 2013}

Nejdříve zaměříme pozornost na průměrné hodnoty použitých ukazatelů, tedy využitých zdrojů financování měřených ukazatelem debt/equity ratio (D/E), dlouhodobých aktiv ve vztahu k celkovému majetku (TANG) a rentabilitu vlastního kapitálu (ROE) v jednotlivých zemích. Tuto situaci dokumentují obrázky č. 1 až č. 4. Tmavá čára $v$ grafech na úrovni hodnoty 1 naznačuje rovnoměrné využití vlastních a cizích zdrojů financování. Hodnoty nad její úrovní signalizují větší míru využití cizích zdrojů financování.

Obrázek 1: Vývoj průměrných hodnot jednotlivých ukazatelů a jejich vzájemný vztah ve stavebnictví České republiky v letech 2006 až 2013
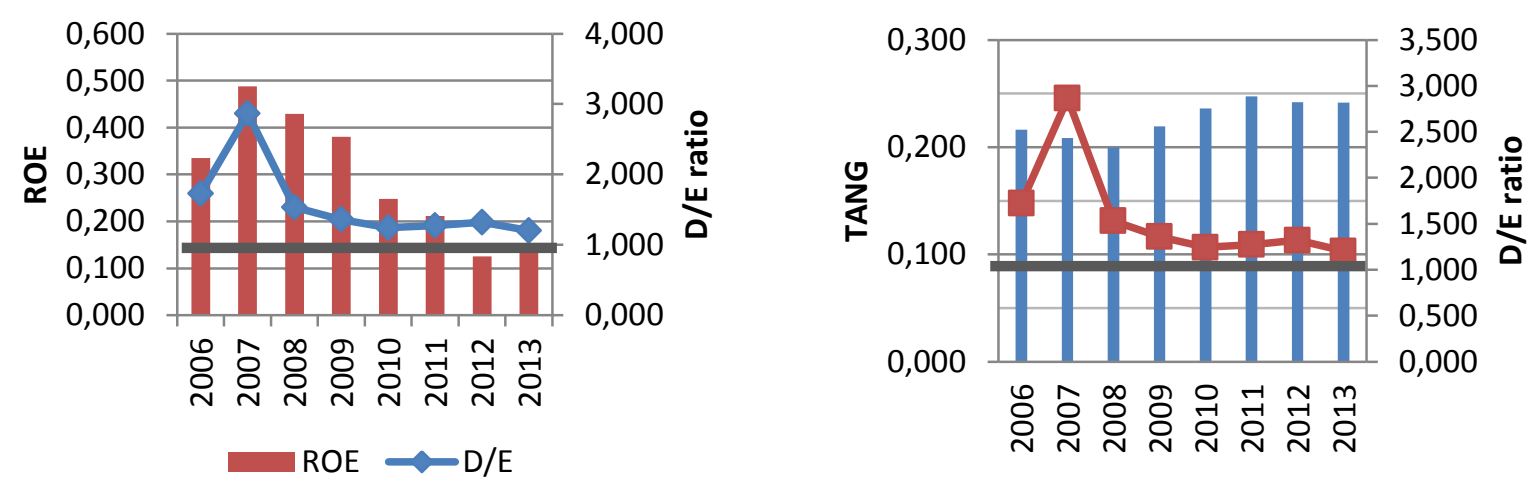

Zdroj: vlastní zpracování dle podkladů z databáze Amadeus

Z obrázku č. 1 je patrné, že hlavním posuzovaným ukazatelem je $\mathrm{D} / \mathrm{E}$ ratio. Je patrné, že ve všech sledovaných letech se hodnoty pohybují nad úrovní 1 , což signalizuje větší míru využití cizích zdrojů financování. Je však také patrné, že využití cizích zdrojů financování $\mathrm{v}$ letech klesá a nejnižších hodnot je dosaženo v posledním sledovaném roce. $\mathrm{V}$ něm se téměř vyrovnává poměr mezi využitým vlastním a cizím kapitálem. Tento vývoj je pochopitelný především v kontextu vývoje stavební produkce, kde podle Euroconstructu (2014) od roku 2009 klesá tempo stavební produkce. Největší propad je zaznamenán v roce 2013, což dokumentuje také tabulka č. 1. Dle Kvartální analýzy (01/2014) rok 2013 byl již pátým rokem pokračujícího poklesu českého stavebnictví. Stavební produkce za rok 2013 klesla o 8,2 procenta a ve srovnání se svým vrcholem v roce 2008 pokleslo stavebnictví až o čtvrtinu 
(25,1 \%). S výjimkou zlomového roku 2008, kdy rozsah blížící se krize ještě nebyl patrný, a roku 2009, kdy naopak v sektoru vypukla panika ohledně reálně nastoupivší krize. Větší sklon k nezadlužování si lze vysvětlit především ve vnímaném riziku z hlediska nároků na financování do budoucna a také sníženou ochotou investovat v podmínkách nejistého ekonomického prostředí.

Tabulka 1: Meziroční tempo vývoje stavební výroby v České republice v letech 2008 až 2013

\begin{tabular}{|c|c|c|c|c|c|c|}
\hline & 2008 & 2009 & 2010 & 2011 & 2012 & 2013 \\
\hline Česká republika & $2,70 \%$ & $-1,30 \%$ & $-7,3 \%$ & $-3,8 \%$ & $-7,7 \%$ & $-8,2 \%$ \\
\hline
\end{tabular}

Zdroj: Euroconstruct. 76. konference Euroconstruct v Praze [online]. [vid. 1.9.2014]. Dostupné z: http://www.financninoviny.cz/zpravy/evropske-stavebnictvi-je-letos-na-svem-dne-ceske-bude-klesat/1013942

Průměrný objem dlouhodobých aktiv se od roku 2011 stabilizoval na hodnotě blízké $25 \%$. Je tedy zřejmé, že vývoj stavební produkce se projevil spíše růstem a následnou stabilizací objemu stálého majetku. Relativně nízký podíl dlouhodobého majetku je ve stavebnictví obvyklý, nebot' realizace zakázek různého typu vyžaduje rovněž flexibilitu $z$ hlediska využívané techniky. Stavební společnosti pak častěji využívají operativní leasing na techniku, která by pro jiné zakázky nenašla uplatnění. Z hlediska účetního se pak tento zdroj financování nepromítá na straně pasív, ale na straně aktiv v účtech časového rozlišení. Tempu vývoje stavební výroby také odpovídá vývoj hodnot rentability vlastního kapitálu. To znamená, že i u ROE je možné zaznamenat propad hodnot až do roku 2011. Rok 2012 je ve znamení mírného nárůstu, což je rozdíl oproti tempu vývoje stavební produkce, ovšem rok 2013 se k propadu zase vrátil. Obrázek č. 1 také naznačuje, že z hlediska vztahu využití cizích zdrojů financování a podílu dlouhodobého majetku k celkovým aktivům je možné sledovat spíše protichůdnou vývojovou tendenci. Naopak ROE a D/E naznačují z hlediska vzájemného vztahu podobný vývojový trend. Tato problematika je u průměrných hodnot níže řešena použitím korelace.

V Mad'arsku v roce 2013 - po několika letech poklesu ve stavebnictví - byla stavební výroba o 9,6\% vyšší než v předchozím roce a její hodnota činila 1 793,6 mld. HUF. Zvýšila se produkce v obou hlavních skupinách. Objem stavby budov byl o 10,4 \% vyšší než v předchozím roce a činil 914,6 mld. HUF. Zvýšení bylo způsobeno hlavně výstavbou průmyslových budov, naproti tomu se stavby bytů i nadále snižovaly. Ostatní stavby se zvýšily o 8,6 \% (879 mld. HUF) a to díky pracím na rozvoji dopravní infrastruktury. V rámci podnikání ve stavebním průmyslu bylo za rok 2013 uzavřeno o 29,5 \% nových smluv a jejich hodnota činila 2005,8 mld. HUF. Výrobní ceny stavebního průmyslu se ve stavebnictví v roce 2013 zvýšily v průměru o 1,9 \%. Mad'arské stavebnictví je z hlediska průměrných hodnot sledovaných ukazatelů odlišné od situace v České republice. Stav a vývoj ukazatelů dokumentuje obrázek 2 . 
Obrázek 2: Vývoj průměrných hodnot jednotlivých ukazatelů a jejich vzájemný vztah ve stavebnictví Mad’arska v letech 2006 až 2013

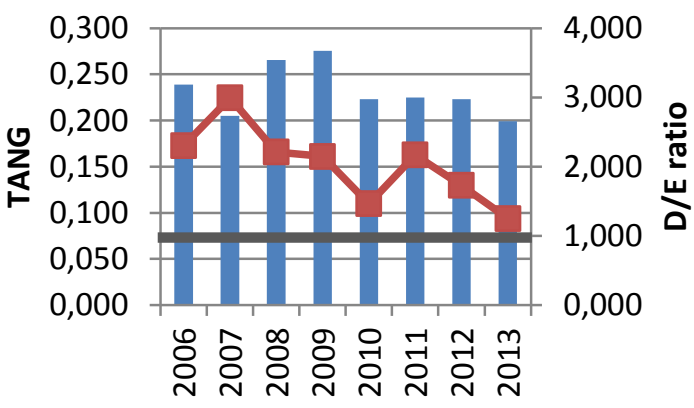

TANG $-D / E$

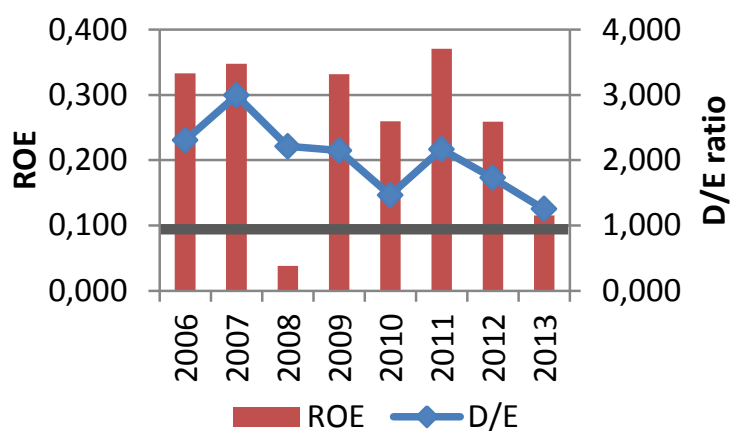

Zdroj: vlastní zpracování dle podkladů z databáze Amadeus

Z obrázku 2 je patrné, že v letech 2006 až 2013 výrazně pokleslo využití cizích zdrojů financování. Zatímco na počátku sledovaného období byl objem využívaných cizích zdrojů 2-3krát větší než objem vlastních zdrojů, rok 2013 už vykazuje průměrné hodnoty na úrovni vyrovnaného poměru mezi vlastními a cizími zdroji financování. Hodnocení v kontextu s vývojem fixních aktiv naznačuje, že s poklesem využití cizích zdrojů financování klesal i podíl fixních aktiv. Zajímavá je i skutečnost, že ačkoliv se situace z hlediska tempa růstu vývoje stavební výroby v letech 2012 a 2013 vylepšovala (viz tabulka 2), využití cizích zdrojů dále klesalo a klesal i podíl dlouhodobého majetku. To může mít spojitost také s enormním poklesem rentability vlastního kapitálu, která ve sledovaném období vykázala velmi výrazný pokles zejména v období 2011 až 2013. Z obrázku 2 vpravo je patrné, že vývoj rentability a využití cizích zdrojů financování má podobný charakter.

Tabulka 2: Meziroční tempo vývoje stavební výroby v Mad'arsku v letech 2008 až 2013

\begin{tabular}{|c|c|c|c|c|c|c|}
\hline & 2008 & 2009 & 2010 & 2011 & 2012 & 2013 \\
\hline Mad'arsko & $-3,40 \%$ & $-8,97 \%$ & $-9,4 \%$ & $-9,7 \%$ & $-4,3 \%$ & $9,6 \%$ \\
\hline
\end{tabular}

Zdroj: Euroconstruct. 76. konference Euroconstruct v Praze [online]. [vid. 1.9.2014]. Dostupné z: http://www.financninoviny.cz/zpravy/evropske-stavebnictvi-je-letos-na-svem-dne-ceske-bude-klesat/1013942 a http://www.businessinfo.cz/cs/clanky/madarsko-ekonomicka-charakteristika-zeme-18568.html

Polské stavebnictví oproti situaci v České republice a Mad'arsku nemá za sebou krizový vývoj $\mathrm{z}$ hlediska tempa poklesu, tabulka 3 dokládá, že růst byl zastaven až v roce 2012 a teprve pro rok 2013 je zaznamenán výrazný pokles o $12 \%$. Hluboký pokles oboru je do jisté míry důsledkem vysoké srovnávací základny v roce 2012, kdy zejména v 1. pol. 2012 kulminovaly dokončovací stavební práce před EURO 2012. (BusinessInfo, 2014) S cílem uspíšit realizaci investic, byl novelizován zákon o investicích. Proces realizace investice byl zkrácen, především proces získávání pozemků potřebných pro výstavbu silnic. Zákon nahradil dvě rozhodnutí (rozhodnutí o stanovení lokalizace silnice a rozhodnutí o povolení stavby) jedním rozhodnutím (rozhodnutí o povolení realizace investice). Z obrázku 3 je také patrné, že zatímco $\mathrm{v}$ předchozích dvou zemích bylo možné zaznamenat pokles ochoty využívání cizích zdrojů financování, tak Polsko má opačnou vývojovou tendence. 
Obrázek 3: Vývoj průměrných hodnot jednotlivých ukazatelů a jejich vzájemný vztah ve stavebnictví Polska v letech 2006 až 2013
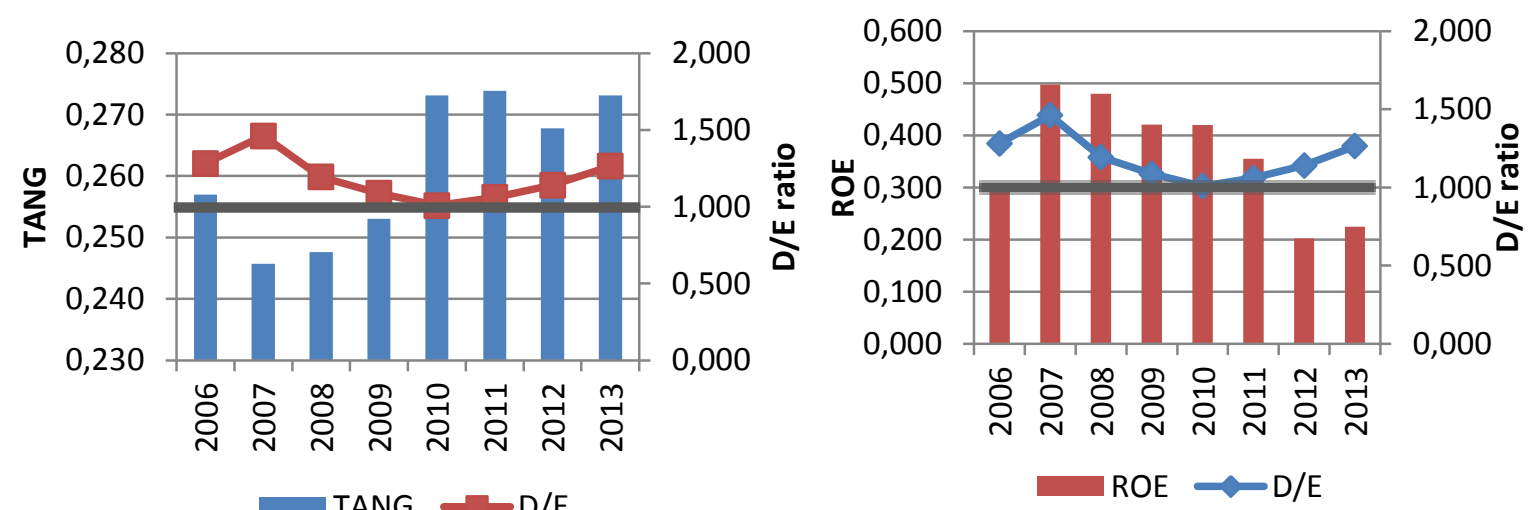

Zdroj: vlastní zpracování dle podkladů z databáze Amadeus

Z hlediska vzájemného vztahu využití cizích zdrojů financování a dlouhodobého majetku na celkových aktivech je také možné zaznamenat, že v první polovině sledovaného období vykazuje vývoj hodnot protichůdnou tendenci od roku 2010 je vývojová tendence podobná. To znamená, že je možné v Polsku zaznamenat růst podílu dlouhodobého majetku při větším využití cizích zdrojů financování. Podobně rozdělený je i pohled na vztah rentability vlastního kapitálu a využití cizích zdrojů financování. V letech 2006 až 2010 je vidět v grafu 3 vpravo, že vývojová tendence je podobná a rozcházet se začíná až v rozmezí let 2011 až 2013. To znamená, že v posledních třech letech s rostoucím využitím cizího kapitálu klesá rentabilita vlastního kapitálu.

Tabulka 3: Meziroční tempo vývoje stavební výroby v Polsku v letech 2008 až 2013

\begin{tabular}{|c|c|c|c|c|c|c|}
\hline & 2008 & 2009 & 2010 & 2011 & 2012 & 2013 \\
\hline Polsko & $11,40 \%$ & $4,30 \%$ & $4,6 \%$ & $11,6 \%$ & $0 \%$ & $-12 \%$ \\
\hline
\end{tabular}

Zdroj: Euroconstruct. 76. konference Euroconstruct v Praze [online]. [vid. 1.9.2014]. Dostupné z: http://www.financninoviny.cz/zpravy/evropske-stavebnictvi-je-letos-na-svem-dne-ceske-bude-klesat/1013942

Rok 2013 byl již pátým rokem pokračujícího poklesu slovenského stavebnictví. Meziročně poklesla stavební produkce na Slovensku o 5,3\%, přičemž v porovnání s rokem 2008 je propad téměř třetinový (situaci dokumentuje také tabulka 4). Pokud bychom však zaměřili pozornost pouze na velké a střední firmy, tak v nich podle kvartálních analýz (CEEC, 2014) již segment velkých firem naznačil oživení a růst na úrovni $1,7 \%$ a pro segment velkých a středních firem odhaduje na rok 2014 oživení na úrovni 1,2\%.

Tabulka 4: Meziroční tempo vývoje stavební výroby na Slovensku v letech 2008 až 2013

\begin{tabular}{|c|c|c|c|c|c|c|}
\hline & 2008 & 2009 & 2010 & 2011 & 2012 & 2013 \\
\hline Slovensko & $10,97 \%$ & $-12,71 \%$ & $-3,6 \%$ & $-2,8 \%$ & $-13,8 \%$ & $-5,3 \%$ \\
\hline
\end{tabular}

Zdroj: Euroconstruct. 76. konference Euroconstruct v Praze [online]. [vid. 1.9.2014]. Dostupné z: http://www.financninoviny.cz/zpravy/evropske-stavebnictvi-je-letos-na-svem-dne-ceske-bude-klesat/1013942 (staženo 1.9.2014) a Slovenský statistický úřad 
Obrázek 4: Vývoj průměrných hodnot jednotlivých ukazatelů a jejich vzájemný vztah ve stavebnictví Slovenska v letech 2006 až 2013

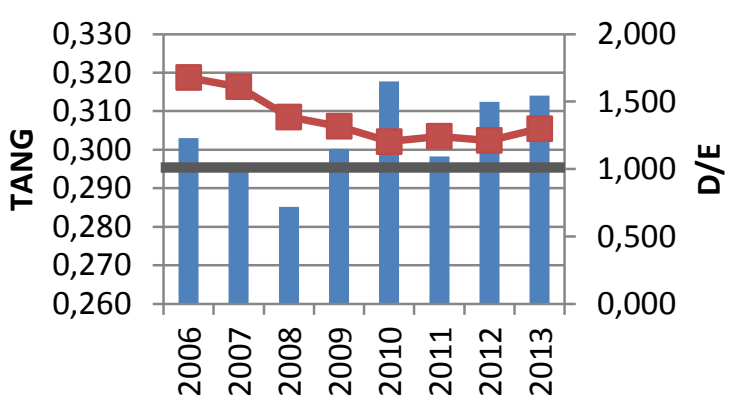

TANG $-D / E$

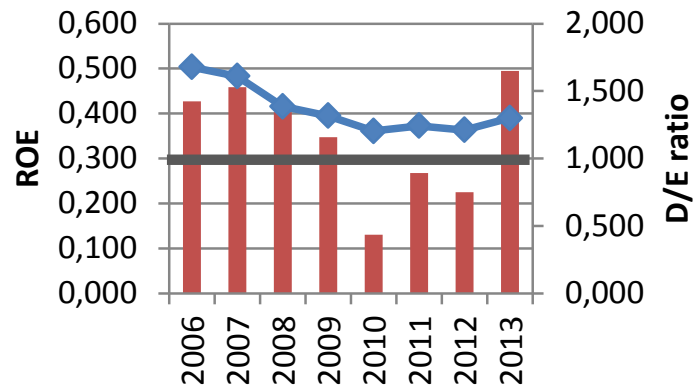

ROE $\longrightarrow$ D/E

Zdroj: vlastní zpracování dle podkladů z databáze Amadeus

Z vývoje použitých zdrojů financování ve slovenských stavebních firmách (obrázek 4) je možné vyčíst, že stavební společnosti využívají ve všech sledovaných letech více cizích zdrojů financování, avšak podíl využití cizích zdrojů financování klesá až do roku 2010. V dalších letech je již vývojová tendence nejednoznačná. V posledním sledovaném období využití cizích zdrojů financování znovu roste. Je možné říci, že i na Slovensku vývoj zdrojů financování koresponduje s celkovým vývojem odvětví v zemi. S poklesem využití cizích zdrojů financování roste podíl dlouhodobého majetku, takže pro Slovensko nelze konstatovat, že by růst dlouhodobého majetku podpořil ochotu využívat cizí zdroje. Je však také patrné, že slovenské stavební firmy mají největší podíl dlouhodobého majetku ve všech sledovaných zemích. Rentabilita v obrázku 4 vpravo vykázala mezi lety 2007 až 2010 velmi výrazný pokles. V následujících letech je vývoj nevyrovnaný a až v posledním sledovaném roce je patrný velmi výrazný růst rentability.

Ukazatele by podle teorií a výše uvedených studií měly vykazovat vzájemnou závislost. Jedním ze způsobů, jak tuto závislost měřit, je pomocí korelačního koeficientu. Využití korelačního koeficientu sice nenaznačí směr závislosti, ale bude měřit její míru. Korelace je vyjádřena pomocí následující rovnice (2).

$$
k_{X Y}=\frac{\operatorname{cov}(X, Y)}{\sigma_{X} \sigma_{Y}}
$$

kde X je střední hodnota matice hodnot debt/equity ratio a Y je střední hodnota matice hodnot rentability vlastního kapitálu vždy v jednotlivých zemích. Hodnoty tohoto ukazatele by se měly pohybovat $\mathrm{v}$ intervalu od -1 do 1 . Hodnoty bližší hodnotě 1 by pak naznačovaly, že s růstem využití cizích zdrojů roste rentabilita vlastního kapitálu a opačně. Hodnoty rovny nule signalizují vzájemnou nezávislost. Následující obrázek 5 vyjadřuje míru vzájemné závislosti sledovaných veličin $\mathrm{v}$ jednotlivých zemích. 
Obrázek 5: Korelace vybraných veličin ve vztahu $\mathrm{k} \mathrm{D} / \mathrm{E}$ ratio $\mathrm{z}$ hlediska průměrných hodnot ukazatelů v jednotlivých zemích v období 2006 až 2013

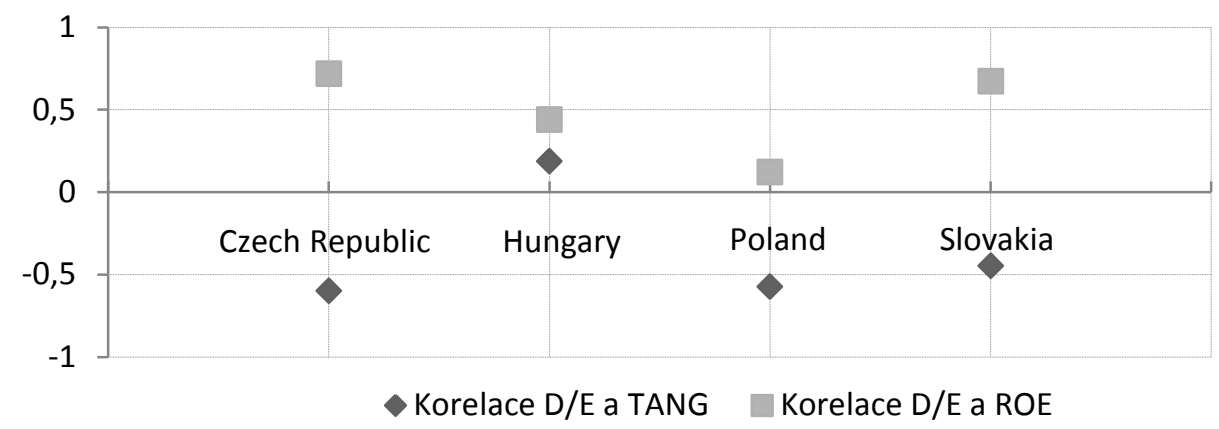

Zdroj: vlastní zpracování dle podkladů z databáze Amadeus

Při hodnocení párového vztahu pomocí korelace bylo zjištěno, že z hlediska vztahu využití cizích zdrojů financování a dlouhodobého majetku na celkových aktivech je možné vysledovat negativně korelovaný vztah v České republice, Polsku a na Slovensku. Opačnou tendenci je možné sledovat pouze v Mad'arsku. V návaznosti na hypotézu H1 - s růstem objemu dlouhodobého majetku roste využití cizích zdrojů financování - lze tedy konstatovat, že tato hypotéza na průměrných hodnotách byla potvrzena pouze v Mad'arsku. Ostatní země ji nepotvrdily. Ve všech zemích, i když s rozdílnou mírou korelace, však můžeme vidět, že růst využití cizích zdrojů financování přispívá k růstu rentability a opačně. V tomto směru však párová korelace neposkytuje dostatečnou míru vypovídací schopnosti, nebot' nenaznačuje jasně vztah závislosti, tedy nedefinuje jasně závislou a nezávislou veličinu. Také proto je další analýza zaměřena na modelování na vzorku společností, kde je již funkční závislost jasně naznačena rovnicí. I přes tyto nedostatky bude nesporně zajímavé sledovat, zda bude možné sledovat stejnou funkční závislost ve vzorku v panelu, jako u průměrných hodnot.

\section{Analýza funkčního vztahu průmyslového odvětví stavebnictví}

Při použití GMM modelu ve vzorku společností, tak jak byl vymezen v úvodu tohoto článku, byla nejprve pozornost zaměřena na to, jak je vývoj použití cizích zdrojů financování (DER) ovlivněn dosahovanou efektivností a využitím cizích zdrojů v předchozím období. Vztah je vyjádřen následující rovnicí (3):

$$
D E R_{i t}=\alpha_{1}+\beta_{1} * \Delta D E R_{i t-1}+\beta_{2} * T A N G_{i t}+\varepsilon_{i t}
$$

kde endogenní závislá proměnná $D E R_{i t}$ představuje vývoj debt/equity ratio i-té proměnné $\mathrm{v}$ čase $\mathrm{t}$ a hodnotí využití financování cizími zdroji, exogenními nezávislými proměnnými jsou zpožděná hodnota debt/equity ratio z predchozího roku $\Delta D E R_{i t-1}$ a vývoj podílu dlouhodobých aktiv na celkové hodnotě aktiv $T A N G_{i t}$. Symboly $\alpha_{1}$ a $\varepsilon_{i t}$ jsou konstantou modelu a reziduální složkou v modelu GMM. Volba výše uvedených ukazatelů také vychází z již realizovaných studií (např. Nivorozhkin (2005), Hernardi, Ormos (2012), Crnigoj (2009), Růčková (2013)), které zohledňovaly specifika evropského prostředí, zejména pak slabší dostupnost tržních dat. Právě nedostupnost tržních dat neumožňuje aplikaci studií realizovaných ve Spojených státech amerických, nebot' většina jejich modelů využívá jako faktor především tržní hodnotu podniku. Situace je modelována na vzorku společností ze zemí Visegradské čtyřky. 
Tabulka 5: Debt/equity ratio jako závislá veličina

\begin{tabular}{|c|c|c|c|c|}
\cline { 2 - 5 } \multicolumn{1}{c|}{} & Czech Republic & Hungary & Poland & Slovakia \\
\hline$\beta_{1}$ & $-0,118861^{\mathrm{a}}$ & $0,550524^{\mathrm{a}}$ & $-0,007575^{\mathrm{a}}$ & $0,511927^{\mathrm{a}}$ \\
\hline$\beta_{2}$ & $-55,2745^{\mathrm{a}}$ & $0,729325^{\mathrm{a}}$ & $-45,2148^{\mathrm{a}}$ & $-24,4115^{\mathrm{a}}$ \\
\hline S.E. of regression & 7,099692 & 3,440626 & 4,85 & 6,71475 \\
\hline
\end{tabular}

Poznámka: Symbol ${ }^{a}$ znamená statistickou významnost na hladině $1 \%$

Zdroj: vlastní zpracování

V tabulce 5 sledujeme vliv majetkové struktury podniku na využití zdrojů financování. Z tabulky je patrné, že vliv podílu stálého majetku na celkové hodnotě aktiv má na míru využití cizích zdrojů financování rozdílný vliv. Z tohoto pohledu lze konstatovat, že v České republice, Polsku a na Slovensku je vliv stejný, tedy negativní. S růstem objemu dlouhodobého majetku klesá využití cizích zdrojů financování. Pro Polsko a Českou republiku lze stejně vyhodnotit vztah využití dalších cizích zdrojů, nebot' i zde byl zaznamenán negativní vztah. To znamená, že pokud byly využity v rostoucí míře cizí zdroje v předchozím období, využití cizích zdrojů financování v následujícím období klesá. Slovenská republika se vyznačuje jiným vztahem využití cizích zdrojů v předchozím období a využití cizích zdrojů ve stávajícím období. Mad’arsko vykazuje stejný funkční vliv jak $\mathrm{z}$ hlediska využití cizích zdrojů v předchozím období, tak $\mathrm{z}$ hlediska vlivu dlouhodobého majetku. Závislost je v tomto ohledu pozitivní, což znamená, že s růstem dlouhodobého majetku roste využití cizích zdrojů financování. Porovnáme-li výsledky modelu GMM na vzorku a párové korelace na průměrných hodnotách, tak můžeme říci, že výsledky z modelu GMM potvrdily výsledky korelace, nebot' závislosti vyšly stejně. Model se však vyznačuje jasným nastavením závislé a nezávislé veličiny. Proto i z hlediska modelování je možné konstatovat, že pro Českou republiku, Polsko a Slovensko nelze potvrdit hypotézu H1. Nevýhoda párové korelace je také v tom, že je možné zkoumat pouze vztah dvou veličin, model GMM nám umožnil do rozhodování zapracovat také vliv rentability vlastního kapitálu, která při získávání zdrojů financování z bankovního sektoru hraje roli z hlediska stanovení ceny úvěru. Ve vztahu k ochotě využít cizí zdroje financování by tak měl být zaznamenán pozitivní funkční vliv, nebot' dlouhodobě rostoucí ROE zlepšuje image a stabilitu společnosti a umožňuje získávat levněji zdroje z bankovního sektoru. Dalším předmětem zkoumání bylo zapracování vlivu rentability vlastního kapitálu. Model by měl objasnit, jaký vliv má na využití cizích zdrojů financování nejen majetkové vybavení společnosti, ale také rentabilita vlastního kapitálu. Vztah je vyjádřen následující rovnicí (4):

$$
D E R_{i t}=\alpha_{1}+\beta_{1} * \Delta D E R_{i t-1}+\beta_{2} * T A N G_{i t}+\beta_{3} * R O E+\varepsilon_{i t}
$$

kde endogenní závislá proměnná $D E R_{i t}$ představuje využití cizích zdrojů financování i-té proměnné $\mathrm{v}$ čase $\mathrm{t}$, exogenními nezávislými proměnnými jsou zpožděná hodnota DER z předchozího roku $\triangle D E R_{i t-1}$, vývoj míry dlouhodobého majetku na celkové hodnotě aktiv $T A N G_{i t}$ a vývoj rentability vlastního kapitálu $R O E$. Symboly $\alpha_{1}$ a $\varepsilon_{i t}$ jsou konstantou modelu a reziduální složkou v modelu GMM. Situace je opět modelována pro vzorek společností všech zemí Visegradské skupiny.

Tabulka 6: Debt/equity ratio jako závislá veličina

\begin{tabular}{|c|c|c|c|c|}
\cline { 2 - 5 } \multicolumn{1}{c|}{} & Czech Republic & Hungary & Poland & Slovakia \\
\hline$\beta_{1}$ & $-0,01641^{\mathrm{a}}$ & $0,534498^{\mathrm{a}}$ & $0,028113^{\mathrm{a}}$ & $0,678280^{\mathrm{a}}$ \\
\hline$\beta_{2}$ & $-10,449^{\mathrm{a}}$ & $1,208154^{\mathrm{a}}$ & $-10,8383^{\mathrm{a}}$ & $-25,65342^{\mathrm{a}}$ \\
\hline$\beta_{3}$ & $22,51694^{\mathrm{a}}$ & $0,865662^{\mathrm{a}}$ & $3,036847^{\mathrm{a}}$ & $-18,96053^{\mathrm{a}}$ \\
\hline S.E. of regression & 5,377018 & 3,404576 & 4,393461 & 6,024287 \\
\hline
\end{tabular}

Poznámka: Symbol ${ }^{a}$ znamená statistickou významnost na hladině $1 \%$

Zdroj: vlastní zpracování 
Z tabulky 6 je patrné, že vliv již zmíněných nezávislých veličin, tedy vliv využití cizích zdrojů v minulém období a dlouhodobého majetku se téměř nezměnil. Drobná změna nastala pouze u vlivu využití cizích zdrojů v minulém období u Polska, kde se původně velmi malý negativní vliv změnil na malý pozitivní vliv. Co se týče vlivu rentability vlastního kapitálu, tak v České republice, Mad'arsku a Polsku je možné zaznamenat pozitivní funkční vliv, což by znamenalo, že v těchto zemích ve vzorku společností existuje větší využití cizích zdrojů financování při rostoucí rentabilitě vlastního kapitálu. Výjimku z tohoto funkčního vlivu tvoří vzorek společností ze Slovenska, kde je zaznamenán negativní vliv, což by znamenalo, že v okamžiku, kdy je ve společnostech generován zisk, pak dávají přednost financování z vlastních zdrojů a cizí zdroje jsou využívány méně.

\section{Závěr}

Cílem článku bylo na základě analýzy pomocí panelové regrese a korelace zjistit vliv podílu dlouhodobého majetku a rentability vlastního kapitálu na využití cizích zdrojů financování ve firmách v odvětví stavebnictví v podmínkách Visegradské čtyřky. Byly nadefinovány dvě základní hypotézy, které měly podpořit naplnění cíle. H1: S růstem objemu dlouhodobého majetku v majetkové struktuře podniku roste využití cizích zdrojů financování. H2: Větší využití cizích zdrojů financování je spojeno s rostoucím podílem dlouhodobého majetku a rostoucí efektivností podniku. Výsledky zkoumání vlivu jednotlivých veličin na využití cizích zdrojů financování lze shrnout do následující tabulky 7.

Tabulka 7: Vlivy jednotlivých veličin na využití cizích zdrojů financování podle způsobů zkoumání

\begin{tabular}{|l|c|c|c|c|c|}
\hline & \multicolumn{2}{|c|}{ Vliv u korelace } & \multicolumn{3}{c|}{ Vliv v modelu GMM } \\
\cline { 2 - 6 } & TANG & ROE & $\Delta$ DER & TANG & ROE \\
\hline Czech Republic & - & + & - & - & + \\
\hline Hungary & + & + & + & + & + \\
\hline Poland & - & + & + & - & + \\
\hline Slovakia & - & + & + & - & - \\
\hline
\end{tabular}

Zdroj: vlastní zpracování

Z tabulky 7 je patrné, že obě metody zkoumání vedly ke stejným výsledkům $\mathrm{z}$ hlediska funkčního vlivu jednotlivých veličin na využití cizích zdrojů financování. V České republice, Polsku a Slovensku lze u obou metod konstatovat, že s rostoucím objemem dlouhodobého majetku klesala využití cizích zdrojů financování. Pozitivní funkční vliv je zřejmý pouze v Mad'arsku. Lze tedy konstatovat, že jak při zkoumání metodou korelace, tak při zkoumání v modelu GMM můžeme H1 zamítnout ve třech ze čtyř sledovaných zemí a to jak na průměrných hodnotách, tak hodnotách jednotlivých společností ve vzorcích. Druhá hypotéza bude proto také zamítnuta pro tř́i ze čtyř zemí, nebot' sice pro ČR, Mad'arsko a Polsko zaznamenáváme pozitivní funkční vliv ROE na využití cizích zdrojů, ale rostoucí podíl dlouhodobého majetku vedl k poklesu využití cizích zdrojů. Na Slovensku navíc byl u modelu GMM i negativní vliv růstu rentability vlastního kapitálu. Obě hypotézy byly potvrzeny jen na průměrných hodnotách a hodnotách vzorku stavebních společností v Mad'arsku. 


\section{Literatura}

[1] ANTONIOU, A., Y. GUNEY a K. PAUDYAL, 2002. Determinants of corporate capital structure: Evidence from European Countries. Centre for Empirical Research in Finance, Department of Economics and Finance, University of Durham.

[2] BARCLAY, M., E. MORELLEC a C. W. SMITH, 2001. On the debt capacity of growth options. Working Paper, No. FR 01-07. University of Rochester Bradley Policy Research Center.

[3] BEVAN, A. A. a J. DANBOLT, 2004. Testing for inconsistencies in the estimation of UK capital structure determinants. Applied Financial Economics, 14(1), 55-66. ISSN 1466-4305.

[4] BusinessInfo [online] [vid. 1.9.2014]. Dostupné z: http://www.businessinfo.cz/ cs/zahranicni-obchod-eu/teritorialni-informace-zeme

[5] CEEC, 2014. Kvartální analýzy stavebnictví v jednotlivých zemích 2014 [online]. [vid. 1.9.2014]. Dostupné z: http://www.ceec.eu/research/filter-research-list?iResearchId= $77 \&$ sCountry $=\mathrm{CZ} \&$ s Year $=2014 \&$ do $=$ downloadResearch

[6] ČRNIGOJ, M. a D. MRAMOR, 2009. Determinants of capital structure in emerging European economies: evidence from Slovenian firms. Emerging market financial trade, 45(1), 72-89. ISSN 1558-0938.

[7] Databáze Amadeus 2013.

[8] DeANGELO, H. a R. MASULIS, 1980. Optimal capital structure under corporate and personal taxation. Journal of Financial Economics, 8(1), 3-29. ISSN 0304-405X.

[9] Euroconstruct. 76. konference Euroconstruct v Praze [online]. [vid. 1.9.2014]. Dostupné z: http://www.financninoviny.cz/zpravy/evropske-stavebnictvi-je-letos-nasvem-dne-ceske-bude-klesat/1013942

[10] FRANK, M. a V. GOYAL, 2004. Capital structure decisions: Which factors are reliably important? Working Paper. University of British Columbia.

[11] GAUD, P., E. JANI, M. HOESLI a A. BENDER, 2005. The capital structure of Swiss companies: an empirical analysis using dynamic panel data. European Financial Management, 11(1), 51-69. ISSN 1468-036X.

[12] GROSSMAN, S. J. a O. D. HART, 1982. Corporate financial structure and managerial incentives. The economics of information and uncertainty, pp. 107-140. University of Chicago Press. ISSN 0169-7218.

[13] HAAS, R. a I. LELYVELD, 2010. Internal capital markets and lending by multinational bank subsidiaries. Journal of Financial Intermediation, 19(1), 1-25. ISSN 1042-9573.

[14] HALL, A. R., 2005. Generalized Method of Moments (Advanced Texts in Econometrics). Oxford University Press. ISBN 0-19-877521-0.

[15] HART, O. a J. MOORE, 1994. A Theory of Debt Based on the Inalienability of Human Capital. Quarterly Journal of Economics, 109, 841-880. ISSN 1531-4650.

[16] HERNADI, P. a M. ORMOS, 2012. What managers think of capital structure and how they act: Evidence from Central and Eastern Europe. Baltic Journal of Economics [online]. 12(2), 47-71 [vid. 1.9.2014]. ISSN 1406-099X. Dostupné z: http://ssrn.com/abstract=2200911 
[17] MARSH, P., 1982. The Choice Between Equity a Debt: An Empirical Study. The Journal of Finance, 37(1), 121-144. ISSN 1540-6261. doi: 10.1111/j.15406261.1982.tb01099.x

[18] MICHAELAS, N., F. CHITTENDEN a P. POUTSIOURIS, 1999. Financial policy and capital structure choice in UK SMEs: empirical evidence from company panel data. Small Business Economics, 12(2), 113-130. ISSN 1573-0913.

[19] MYERS, S. C. a N. S. MAJLUF, 1984. Corporate Financing and Investment Decisions when Firms Have Information That Investors Do Not Have. Journal of Financial Economics, 13(2), 187-221. ISSN 0304-405X.

[20] NIVOROZHKIN, E., 2005. Firms' Financing Choices in EU Accession Countries. Emerging Markets Review, 6(2), 138-169. ISSN 1566-0141.

[21] PRUCHA, I. R., 2014. Instrumental Variables/Method of Moments Estimation. In: M. M. FISHER, and P. NIJKAMP, eds. Handbook of Regional Science. ISBN 978-3-64223430-9.

[22] RAJAN, R. G. a L. ZINGALES, 1995. What do we know about capital structure? Some evidence from international data. Journal of Finance, 50(5), 1421-1460. ISSN 15406261.

[23] RƯČKOVÁ, P., 2013. Effect of profitability on the use of finance sources in categories according to profitability of selected business branches. In: Financial Management of Firms and Financial institutions. Ostrava: VŠB-TU Ostrava, Ekonomická fakulta, s. 734745. ISBN 978-80-248-3172-5.

[24] SCOTT, J. H., 1977. Bankruptcy, secured debt, and optimal capital structure. The Journal of Finance, 32(1), 1-19. ISSN 1540-6261.

[25] SHLEIFER, A. a R. W. VISHNY, 1992. Liquidation values and debt capacity: A market equilibrium approach. The Journal of Finance, 47(4), 1343-1366. ISSN 1540-6261.

[26] Slovenský statistický úřad [online] [vid. 1.9.2014]. Dostupné z: http://slovak.statistics.sk/wps/portal/

[27] STULZ, R. a H. JOHNSON, 1985. An analysis of secured debt. Journal of Financial Economics, 14(4), 501-521. ISSN 0304-405X.

[28] TITMAN, S. a R. WESSELS, 1998. The determinants of capital structure choice. Journal of Finance, 43(1), 1-19. ISSN 1540-6261. 